\title{
Legislative Impact on Lending: Credit Risk Management in China ${ }^{1}$
}

\section{Zhaohua Li}

\author{
Lincoln University \\ Faculty of Commerce \\ P. O. Box 84, Christchurch \\ New Zealand 7647 \\ Tel: +64 0211175295 . \\ Email: zhaohuali@lincoln.ac.nz
}

\footnotetext{
${ }^{1}$ The paper is based, in part, on my Ph.D. thesis conducted at National University of Singapore. It has substantially benefited from the support and advice of my supervisor, Takeshi Yamada. I also greatly acknowledge the comments received from Jun Koo Kang, Inmoo Lee, Anand Srinivasan, Clive Smallman, Lam Swee Sum, Deb Reed, two anonymous referees and seminar participants at National University of Singapore, EFMA annual conference 2008, Greece. I would like to thank two anonymous banks for providing the data and the bank officials for the helpful discussions.
} 


\title{
Legislative Impact on Lending: Credit Risk Management in China
}

\begin{abstract}
The Chinese government established the Act on Commercial Banks 1995 to enforce and regulate commercial banking activities. The government envisaged that the Act, together with other bank reforms, would improve credit risk management practice among commercial banks, and hence the banks would reduce and ultimately stop local government directed policy lending to state-owned enterprises (SOEs). This paper examines the lending behavior of a governmentcontrolled commercial bank before and after the passage of the Act. We find that the bank tightened control of the credit risk of borrowers after the passage of the Act. We also find that SOEs are charged a rate of interest higher than that charged to private firms.
\end{abstract}

Key words: Credit risk; SOEs; private borrower; China 


\section{Introduction}

A major objective of bank management is to increase its returns for owners. This, however, often comes at the cost of increased risk. It can be argued that the effective management of these risks is essential to bank performance. For most banks, loans are the largest and most obvious source of credit risk. Should a borrower default, the principal and the interest payments are at risk. In a frictionless capital market, risk is observable, thus effective credit risk management can be achieved through maximizing a bank's risk-adjusted return by maintaining credit exposure within acceptable levels. However, in practice, the credit quality of many banks' lending decisions is poor. One reason is the information asymmetry between lenders and borrowers. Numerous papers have been devoted to study how information asymmetry causes adverse selection and moral hazard behavior of borrowers, and how banks use screening and monitoring to effectively manage credit risk. This line of literature assumes banks have incentives to manage credit. In reality, this is not the case, especially for government banks. State-owned banks firmly believe that they would be bailed out by government should any bankruptcy possibility occur, thus have less incentive to manage credit risk. That is why we see the inefficiency of government banks worldwide (see La Porta et al., 2002; Barth et al., 2004; Berger et al., 2005). Besides the incentive issue, government banks are subject to intervention by politicians who often ask for lending to socially favorable projects or to state-owned enterprises (SOEs). Therefore, it interests us to know what kind of credit risk management exists in a government bank and to ask whether government banks give favorable loan terms to SOEs. The answers to those questions are based more on anecdotal evidence and lack empirical support. 
In this paper, we attempt to fill the gap by examining credit risk management in a stateowned bank in China. In China, the financial system is dominated by the four of the largest state-owned banks. The bank credit/GDP ratio is 1.1 in China, while a sample average of English origin, French origin, German origin and Scandinavian origin countries' bank credit/GDP ratio is 0.73 (Allen et al., 2005). This provides us with a good opportunity to examine credit risk management in the context of government banks.

Before the early 1990s, there existed a weak legal system for banking regulation and supervision in China (Liu, 2000). Most banks were controlled by local governments through administrative means and were not regarded as commercial entities. Instead, they were treated metaphorically by local government as 'automatic teller machines (ATMs)' from which they withdrew money that they directed to state owned enterprises (SOEs). However, many SOEs were unprofitable or inefficient. As a result, local government directed (LGD hereafter) lending accounted for between 20 and 60 per cent of the assets of the four 'state-specialized' banks (Lou 1993). Consequently, a large number of non-performing loans (NPLs thereafter) accumulated.

The large proportion of NPLs seriously affected the profitability of banks, such that the return on assets of banks decreased from 1.4 per cent in 1985 to 0.3 per cent by 1994 (Lardy 1998).

The central government addressed the problem of LGD in the early 1990s by enacting the Act on Commercial Banks 1995. Following this Act, state banks were no longer regarded as policy banks or state-specialized banks, but transformed to state-owned commercial banks. In other words, after 1995, state-owned commercial banks needed to set up criteria to screen borrowers because the Act required the banks to be responsible for their profits and losses. To 
make this move credible, the central government implemented a series of reforms around 1995. The objective was to motivate banks to practice good credit risk management.

Skeptics countered that, despite the intentions of the central government, the change in the banks might not necessarily be effective, citing two main issues. The first factor was the intervention of local governments in bank lending decisions. Many state banks were required to lend to SOEs to support the local economy. If such LGD lending persisted after the Act on Commercial Banks 1995, the Act would be deemed ineffective, impacting the bank's profitability. The second factor is the moral hazard problem within state banks, which arises due to the nature of state ownership and lack of sufficient risk awareness to monitor loans.

In this paper, we assess the impact of the Act on Commercial Banks 1995 on the lending behavior of state banks. Employing a unique database from a state-owned bank in China, we attempt to determine whether the quality of the lending practices of the bank improved after 1995 when the Act on Commercial Banks 1995 was enacted. It is hypothesized that banks strengthened their credit risk control after 1995.

This is a neglected aspect of Chinese bank lending behavior because there are limited studies on state banks in China due to the data collection difficulty. Cull and Xu (2000, 2003) studied banking reform before 1995, finding that bank employees' assessment of SOEs' credit risks was better than the assessment by bureaucrats and there was a positive relationship between bank financing and borrowers' profitability. However, the relationships were weakened after 1990 because banks imposed soft budget constraints on SOEs. Li et al (2001) show that low profitability of state-owned banks results from their higher ratio for non-interest expenses and lower interest margin than joint-equity banks. State-owned banks also generated lower returns with higher financial risks than their Western counterparts. Hwa and Lei (2010) reviewed reform strategy of Chinese state commercial banks and find strong financial performance after 
the reform. Rowe et al. (2009) examine the relation between board governance and profitability of Chinese commercial banks. They find board governance characteristics, such as higher board ownership, lower percentage of insiders on board, and lower block ownership are associated with better bank profitability. Berger et al. (2009) study the efficiency of partially privatized state-owned banks. They find that minority foreign ownership is far more efficient than state ownership in terms of profit and cost efficiency in China. Chang et al. (2009) examine how useful banks' internal credit rating scores are in predicting the default status of commercial loans in a major Chinese state-owned bank. They find that the internal credit ratings are significantly related to loan default and this credit rating measure is associated with commonly used financial ratios as well as specialty information detected by the bank. This paper is different from the literature in three ways. First, the above literature looks at how certain factors affected the outcome of bank performance. None of those papers look at the process of bank lending, that is, what kind of factors affect the loan contract design. Our paper explores the pricing behavior of a Chinese bank, that is, how borrower characteristics and loan characteristics interact with each other, which ultimately affects loan rate. To do this, unlike most papers on bank lending that view loan contract terms independently, we allow for interdependence between loan price and non-price terms in the determination of the loan contract. In this way, we can provide comprehensive evidence on credit risk management practice in China. Second, our sample period is relatively long, and this enables us to examine the impact of the Act on Commercial Bank 1995 on bank lending behavior. Thirdly, we take political factors into consideration and study whether state-owned banks give favorable terms to state borrowers. The findings would be useful to a wider group of policy makers, borrowers, lenders, and investors in evaluating the performance of government banks. 
We use 2,459 commercial loans from a branch of a government-owned bank. In some tables, we split the sample into two periods, 1990-1995 and 1997- $2004^{2}$, and divide borrowers into two groups, SOEs and private firms. Using a simultaneous framework in which the lending rate, maturity, and collateral status are written into the loan contract, we compare the determinants of the interest rate spread in the two periods. Three main findings are presented. First, after 1995, the state bank undertook more rigid screening of its borrowers. Second, we find that the SOEs are charged an interest rate higher than that of private companies by six basis points. Third, we find that shortened loan maturity and use of collateral are used together in the state bank to reduce the information asymmetry. Overall, the results show the change in government bank-lending strategies that have had a positive effect on Chinese commercial banks.

Section two briefly outlines banking reform in China. Section three presents a brief review of the relevant literature and theoretical predictions. Section four describes the sample and data. Section five discusses the methodology and presents the empirical results and section six presents our conclusions.

\section{A Short History of Chinese Banking Reforms}

The Chinese economic reform process officially began in December 1978 at the Third Plenum of the Eleventh Central Committee of the Communist Party of China. Banking reform was a necessary part of the economic reform, and comprised three stages. The first ran from 1978 to 1986. In the initial stage of the reform, the government implemented a new policy that required banks to take over financing functions from the government, which had granted funds to SOEs

\footnotetext{
${ }^{2}$ The exclusion of observations for year 1996 in regression analysis (Table three) is to ensure the results are free from outliers which may occur due to the changes banks had for the adaptation to the newly enacted Act on Commercial Banks 1995.
} 
without interest rate charges. That is, the central bank handed over the deposit and lending business to newly established state-owned specialized banks.

The second stage took place between 1986 and 1994. In 1986, the Provisional Rules Governing Banks were issued. They listed the nature, responsibilities, and business boundaries of the People's Bank (central bank), state-owned specialized banks, and other financial intermediaries. The Rules officially acknowledged that the banking system had changed from being a one-tier system (the People's Bank only) to a two-tier system (the People's Bank and specialized banks and other financial intermediaries). New financial institutions were permitted entry to the banking market and most of them were set up as joint stock banks the shareholders of which were the Ministry of Finance, central government controlled conglomerates, or local government.

However, state-owned specialized banks did not actively manage credit risk; local governments seriously intervened in their lending activities. Many loans were granted on a political basis and charged a low interest rate. To help commercial banks to grant commercially-oriented loans, the third stage reform began in 1995 and continues today. In 1995, the legal basis of the banking regulation system was established by implementing the Act of the People's Republic of China on Commercial Banks 1995 and the Act of the People's Republic of China on the People's Bank of China 1995, along with a number of additional administrative rules and regulations. The key aims of the legislation were to enhance the awareness of credit risk in the lending business among banks (paralleling a similar move by the Bank for International Settlements - Basel Committee on Banking Supervision, 1999) to make commercial banks accountable for profitability and require banks to operate prudential banking operations. 


\section{Theoretical Prediction}

To solve the policy lending problem, three policy lending banks were established to take care of that aspect. As for the moral hazard problem (less incentive to manage credit risk of borrowers) within state banks, it was expected to be improved by the Act on Commercial Banks 1995. However, there is still an element of information asymmetry between borrowers and lenders. Below we explain how different means can be taken in the state bank to reduce the risk arising from information asymmetry in the context of China.

Collateral is an important feature to reduce risk arising from adverse selection and moral hazard problems. Both adverse selection and moral hazard models argue that the use of collateral can minimize the agency costs, but they provide different predictions of what type of borrowers are more likely to provide collateral. The adverse selection model (Bester, 1985; Besanko and Thakor, 1987) argues that banks have less information about risk when borrowers have private information about risk, thus banks would ask borrowers to post collateral to signal the quality. These models predict that better-quality borrowers would more likely provide collateral and pay a lower rate. On the other hand, the moral hazard model (Holmstrom and Tirole, 1997; Boot et al., 1991) states that, after obtaining a loan, borrowers have incentives for asset-substitution when firms take risky debt. These incentives are stronger for low-quality borrowers. Accordingly, banks can ask the borrowers to commit to lower asset substitution by providing collateral. The moral hazard model predicts that when risk is observable, low-quality borrowers are more likely to provide collateral and banks charge a higher rate. It is not clear whether it is the adverse selection or moral hazard problem that is more serious in China. Therefore, we will provide empirical evidence about which effect dominates. 
Similar predictions can be applied to maturity because it is often used by the bank to reduce risk. This agency cost can be minimized by two mechanisms: (i) shortening maturity and asking for collateral together and (ii) either shortening maturity or asking for collateral. The first mechanism suggests that collateral and maturity are complementary. If this is true, we expect to have a negative relationship between the two. The second mechanism is that collateral and maturity are substitutes and are expected to have a positive relationship. In China, institutional and legal frameworks are not well developed and the credit history of borrowers is short. Therefore, we expect information asymmetry to be more serious than in developed countries. We predict the bank would use both collateral and maturity to minimize the risk. Thus we expect to see a negative relation between collateral and maturity.

Relationship lending is also widely explored in the banking literature. The impact of the bank-borrower relationship is captured in relationship length. Conditional on its past experience with the borrower, the lender now expects loans to be less risky. This should reduce the lending rate of the loan over time. However, on the down side, a credible long-term relationship may leave the borrower and bank locked into one another, so the borrower may exploit the bank by paying a lower interest rate or the bank may exploit the borrower by charging a higher interest rate (Sharpe, 1990; Rajan, 1992). Therefore, relationship lending has both upside and downside risk. Which of these is dominant depends on the nature of both the borrower and the bank. Peterson and Rajan (1994) studied the impact of relationship lending on the availability and cost of funds to the borrower. They found that close ties between a firm and its creditor are valuable and that this close relationship increases the availability of financing to the borrower, but not the cost of financing. We are not certain whether the borrower-bank relationship will increase or reduce the interest rate and so we leave it to empirical testing. 
Boot and Thakor (1994) consider the bank-borrower relationship using a model of multiperiod loan contracts in which the lending rate and collateral are determining factors. They argued that long-term contracting under a durable relationship enables the bank to effectively charge lending rates for borrowers through time by reducing the use of collateral. Therefore, banks require collateral from new borrowers and do not require collateral from established borrowers. Their study suggested a negative relationship between the length of a bankborrower relationship and collateral status. China is a country that widely uses collateral and we expect to find this negative relationship between a bank-borrower relationship and collateral.

Diamond (1991) examined how borrowers choose a maturity structure and how their choice depends on their credit rating. Diamond (1991) assumed that a firm is subject to liquidation risk, which is defined as the risk that a firm is unable to pay back its debt and thus will be liquidated by lenders. He argued that good borrowers prefer a short-term debt contract because they can get better lending rates for refinancing when good news arrives. Bad borrowers prefer a long-term debt contract because the liquidation risk is lower compared with the liquidation risk under a short-term debt contract. However, borrowers with very poor rating can borrow only short-term debt because they are rationed out of the long-term debt market. Thus, we expect that borrowers in China have such preferences and expect to find a non-monotonic relation between a firm's credit rating and its debt maturity.

\section{Data and Sample Selection}

The data we use are based on the records of 2,459 commercial loans (after excluding some unusual loans) drawn between 1990 to 2004 from a branch of a government-owned nationwide commercial bank (Bank A) with over 30 per cent state shareholding (the largest in the bank). These are the currently available best databases with complete data series. There are no missing 
values or variables. They have also been corrected (if there were any mistakes) by the internal examiners. Data are for internal use, and should be reliable. This government-controlled joint stock bank had over 2,000 branches and sub-branches and more than 50,000 employees across China by the end of 2004. It is truly a national and general-purpose bank, granting loans across industries to small-, medium-, and large-sized firms. The branch that we examined is located in the middle region of China. It has 25 sub-branches under its control. We believe this sample fairly reflects the general picture of the loan business in China given that the bank reforms and SOEs in the middle region are modest compared with those in the coastal region. There were 654 borrowers, who, on average, had over three loan transactions with the bank. For each loan, we collected information on the contract terms and borrower characteristics. In some of the analysis, we split the sample into two periods, 1990-1995 and 1997-2004, to examine the impact of the Act on Commercial Banks 1995 on the lending behavior of a governmentcontrolled commercial bank, and divided the borrowers into two groups, SOEs and private firms. We exclude observations for 1996 in the regression analysis because the newly enacted Act on Commercial Banks 1995 caused substantial changes within banks. It took some time for this Act to be put into practice so the excluded year's observations will ensure the results free from outliers.

One important fact in the loan business in China is that the interest rate is censored (centrally controlled). The People's Bank sets the basic interest (prime) rate and allows commercial banks to determine the lending rate within a stipulated band around the prime rate. The upper and lower limits vary from time to time and the band has a tendency to widen. The first time that this band was set within the sample period was 1990. However, censoring was not binding until 1995. On October 23, 1997, the People’s Bank set the bank rate at \pm 10 per cent of the basic interest rate for short-term loans (one-year loans). The latest revision of the 
band in the sample period was on June 10,1999 . It was set at -10 percent and +50 per cent of the basic interest rate for both short-term and long-term loans.

Policy lending could be a factor affecting bank lending. However, it is very difficult to identify which loans are 'crony' loans. We observed that there are a few loans that were lent and then returned within one month. The average size of these loans is twice the average loan size. It seems that the bank has an unusual relationship with those borrowers, which may be policy lending. Therefore, we deleted those unusual loans (15 observations).

The credit profile we used specified: (1) the characteristics of the borrower (firm size, relationship length with the bank, SOE or private, industry sector); (2) the characteristics of the credit (interest rate spread, amount of loan, maturity, collateral, and guarantees (acceptance bill)); and (3) the ex ante performance of the loan (credit rating). Full variable definitions are given in the appendix.

Table one shows the basic data about the lending terms in the sample broken down into three sets of characteristics: ownership, collateral, and firm size. There are 2,459 loans granted with a mean of RMB6,970,078 (US\$870,000) per loan, but loan size varies between RMB22,400 (US\$2800) and RMB300,000,000 (US\$37,500,000) ${ }^{3}$. This wide variation is due to the long sample period and the fast growth of Chinese enterprises. The average interest rate spread on loans in our sample is 0.688 . The spread varies considerably from -4.98 to 5.76 per cent. Despite the large variation, the spread of 95 per cent of the loans falls within the band stipulated by the People's Bank.

The maturity of a loan is another important factor in the debt contract. We include it as a proxy for the risk that is associated with the time until the loan is repaid. Most loans from the branch are short term because the average maturity is 9.6 months.

\footnotetext{
${ }^{3}$ The exchange rates of the renminbi against the U.S. dollar from 1990 to 2004 are available from the author.
} 
The relationship characteristics control the information and experience effects. We include the natural logarithm of (one plus) the duration of the relationship in our analysis. A relationship starts from the first time that a firm obtained a loan from the bank. The average duration of the relationship is 1.33 years with the maximum of 7 years.

We also include the bank's own ex ante credit rating on the loan to control the risk. It has a mean of 3.295 on a rating scale where one is the best rating and six is the worst rating. The score is estimated on the basis of a number of factors such as the financial health, industry outlook, past loan performance and growth prospects of the firm. All these factors are associated with default risk and represent a firm's aggregate risk factor.

Panel B shows that SOEs borrow a larger volume and have a lower interest rate spread and longer maturity term than do private firms. The favorable terms are supported by their better credit rating and longer relationship with the bank. Panel $\mathrm{C}$ shows that collateral loans are granted at a larger volume and higher interest spread. These loans have a poorer credit rating than non-collateral loans. This result is consistent with the regulations that are set by the People's Bank and the findings of Berger and Udell (1990) that collateral is most frequently associated with riskier borrowers and riskier loans. Panel D compares the loan characteristics for different borrowers. Small firms borrow at low volume, higher interest rates and for shorter periods. This is probably because their credit rating is poor and their relationship length with the bank is shorter. The situation is reversed for large borrowers. In general, as small firms are more likely to be a greater risk than are large borrowers, the loan terms are less favorable to small firms than to large firms.

In summary, table one gives a general picture of the loan characteristics. We find that favorable loan terms are granted when borrowers have a good credit rating and a longer 
relationship with the bank. Firm size and collateral status are also associated with the risk (credit rating).

Table two describes the debt contract terms, borrower characteristics, and the bank's industry portfolio for SOEs and private firms for the two sub-sample periods.

Panel A, in table two shows that the volume of the loans expanded to six times larger than it was in the first sample period, which suggests the strong financial needs of borrowers. The interest rate spread declines from 2.5 to 2.6 per cent to 0.4 to 0.5 per cent over the sample period, which may largely result from the increased competition among domestic banks. This decline is more severe for SOEs than for private firms. The maturity of the loan is longer, especially for private firms. In general, the average maturity is less than one year, which suggests that most of the loans are short term and used as working capital. With regard to credit rating, we find that the average credit rating of SOEs (2.931) is better than that of private firms (3.311). Finally, the relationship length is longer for borrowers in the second sample period than in the first and it is longer for SOEs than for private firms.

Panel B shows the collateral status and firm characteristics for the two periods and two types of enterprises. Since 1996, 72.3 per cent of private borrowers have provided collateral or guarantees to the bank, while 53.2 per cent of SOEs have done so. The borrower's size is not equally distributed. Most SOEs are medium- and large-sized, while most private firms are small- and medium- sized.

Panel C shows the industry distribution of granted loans. For the first sample period, we find that, for SOEs, the loans are mainly granted to the manufacturing, commercial, and foreign trade industries, and there is not one loan given to any private firm in foreign trade before 1995. This is largely due to the regulation of the foreign trade business. Moreover, it might have been too risky at that time for a private firm, located in the middle region of China, to do 
international trade in the early years of the economic reform. During the period from 19972004, we find that the industry distribution is more diversified for the two types of firms. The bank granted more loans in the commercial sector and fewer loans in the manufacturing sector for private borrowers. The loans in the private commercial sector account for 41.3 per cent of the loans that are granted to private firms compared with 28.6 per cent in the manufacturing sector. The bank also granted fewer loans in the manufacturing sector and more loans in the foreign trade sector to SOEs.

\section{Methodology and Results}

Our paper follows the studies of Diamond (1991), Boot and Thakor (1994), and Rajan (1992) and tests their predictions in the simultaneous equation framework that was proposed by Dennis et al. (2000). To reflect the joint consideration of the contract terms, they model the choice of maturity and collateral status and then model the lending rate and commitment fee, which are determined by the choice of maturity and collateral status. We follow their methodology, but consider only the first three contract terms and ignore the commitment fee because the bank in our sample does not have a commitment fee in its loan pricing. The model takes the following form:

$$
\begin{array}{ll}
\text { Maturity }=\gamma_{1} \text { Collateral }+\beta_{1}^{\prime} X_{1}+e_{1}, & \text { Equation (1) } \\
\text { Collateral }=\gamma_{2} \text { Maturity }+\beta_{2}^{\prime} X_{2}+e_{2}, & \text { Equation (2) } \\
\text { Interest rate spread }=\gamma_{3} \text { Collateral }+\gamma_{4} \text { Maturity }+\beta_{3}^{\prime} X_{3}+e_{3}, & \text { Equation (3) }
\end{array}
$$

where Collateral is a discrete $[1,0]$ variable, and the interest rate spread is the difference between the loan rate and prime rate; ${ }^{\gamma_{i}}$ are the coefficients of the interdependence effects between the contract terms; $\mathrm{Xk}(\mathrm{k}=1$ to 3$)$ are the vectors of the other explanatory variables 
with $\beta_{K}$ representing the effect of the contract terms on those three debt features; and eK are the residuals.

Following Diamond (1991), we include firm size, credit rating, and the square of credit rating as explanatory variables in equation (1) to capture the non-monotonic relationship between credit rating and the maturity of a loan. In equation (2) we include firm size, credit rating, and relationship length as explanatory variables to test Boot and Thakor's (1994) finding that there is a negative relationship between loan collateral and relationship length.

A difficulty in estimating these simultaneous equations is that the dependent variables include a mix of discrete choice (collateral), continuous (maturity), and censored (interest rate) variables. Our approach is to apply a two-stage estimation procedure for simultaneous equation models with limited dependent variables. In the first stage, we use the maximum likelihood method to estimate a reduced form model for each of the endogenous variables. Then, in the second stage, the structural parameters are estimated by substituting the reduced form fitted values for the endogenous variables using the least squares methods.

\subsection{Bank lending rates before and after 1995}

Table three presents the regression estimation of equations (1), (2), and (3). We split the sample into two periods, 1990-1995 and 1997- 2004 in table three. The exclusion of observations for year 1996 in regression analysis is to ensure the results are free from outliers that may occur due to the changes banks had for the adoption of the newly enacted Act on Commercial Banks 1995.

\subsubsection{Loan pricing for SOEs and private firms}


The regression results in columns three and six of Table three show the determinants of the interest rate spread during the two periods.

The coefficient on State is not significant in 1990-1995 period, but is significant in the 19972004 period. It suggests that ownership was not an important element in the debt contract before the Act. We also find that SOEs paid slightly higher interest rates than private borrowers by 6.8 basis points from 1997 to 2004 . This result is different from the conventional view that SOEs receive 'soft' loans from state banks. To reconcile the problem, we need to note that the descriptive statistic in table two shows that SOEs are, on average, charged a lower interest rate. However, the descriptive statistic simply compares the interest rate differences whereas the simultaneous regression analysis is based on multiple factors after controlling for endogeneity, interest rate censoring, etc. To enhance the credibility of the results, we interviewed the bank officials. They were not surprised by the results and gave an explanation that the state firms cared less about the borrowing cost, while private firms cared more about the cost of debt, which enabled the Bank to charge higher lending rates and take advantage of the SOEs. To validate this argument, we split the sample into listed firms versus unlisted firms. Within the listed firm sample, state borrowers have access to the stock market; we expect that the bank does not have the bargaining power to charge high interest rates to state firms that are also listed firms. Consistent with this conjecture, we find that the coefficient on State is not significant in the listed firms' sample. We also conducted the same analysis for the unlisted firms sample and the results were similar to the main results in table three. ${ }^{4}$

For a follow-up investigation, we report the interest rate charged to SOEs and private firms year by year in panel A of table four. The t statistic is reported after 1994 because there are not enough observations for the $\mathrm{t}$ statistic before 1994. The differences in interest rates are

\footnotetext{
${ }^{4}$ The results are not reported here and are available from the author upon request.
} 
significant for only three years, suggesting that most of time the SOEs do not necessarily obtain favorable prices. SOEs paid a lower interest rate in 1999 and 2004, but they also received lower loans by USD257,000 and USD536,585 on average per each loan. The only puzzling year is 2000 where SOEs received a low lending rate and large loan amounts at a similar credit rating. The observations that year were 145 , which is relatively small. Thus, the simple statistics do not support the conventional view after the initiation of Act on Commercial Banks 1995.

Another way to study whether SOEs receive 'soft' loans is to examine the sample of eliminated customers. Every year, the bank eliminates certain customers, which, by definition, the bank would not give loans to in the future. Panel B of Table four reports the number of customers being eliminated per year. We find that the number peaked in year 1997, and then went down. In general, the difference between SOEs and private borrowers is not significant.

Thus the sample shows that there is no particular bias in terms of ownership in eliminating poor borrowers.

The coefficient on State*redit_rating is significant at 0.046 . This coefficient suggests that the interest rate spread increases by 4.6 basis points for state loans if the credit rating changes one point. The credit ratings for private firms are not significant possibly due to the credit rationing effect, i.e., bad private borrowers might have been rationed out of the credit market.

Our results suggest that the bank has strengthened its credit risk control for SOEs. There are several possible factors that could drive the results. First, government intervention was reduced after 1998. In 1998, the People's Bank replaced its 30 provincial branches with nine crossprovince regional branches with the aim to reduce the influence of local governments on bank lending activities. The bank officials were replaced by new staff who had little connection with the local government. Second, SOEs are more risky than private firms due to the massive reforms applied to SOEs in late 1990s. The biggest uncertainty associated with SOEs' reform is 
that local government may not bail out the SOEs if they were not performing well. These two factors are not applicable to private firms and that could be a reason that the bank would charge slightly higher interest rates for SOEs that have low credit ratings.

\subsubsection{Interdependence}

The coefficients of the contract feature the interdependence term, $\gamma_{i}$, which are also of interest. There is strong evidence that the choice of contract features is interrelated with six of the eight interdependence terms being statistically significant at the $99 \%$ confidence level. These results provide support for the use of the simultaneous equation framework that choices of loan features are interrelated. Moreover, we find that there is a negative relationship between the collateral status of a loan and the maturity of a loan in both periods. This relationship was weaker from 1990-1995. This result supports our prediction that information asymmetry is more serious in China so shortening maturity and asking for collateral complement each other in Chinese banks to reduce information asymmetry. This result is also consistent with Denis et al. (2000)

\subsubsection{Contract design}

We find strong evidence for several predictions concerning loan contract design as discussed in section 3 as well as current literature.

The length of maturity has an impact on loan pricing. In column three of table three, the coefficient of maturity is significantly negative at the one per cent level: an increase in maturity from, for example, one year to two years, reduces the loan rate by 142.4 basis points. When we tabulate the loan rate versus maturity, we see a clearly downward slopping yield curve, especially for loans with less than one year maturity. The negative effect of maturity on the 
loan rate is consistent with the result in Degryse and Ongena (2005). They find that the negative relation holds for loans with a maturity shorter than five years, but when loans have a maturity longer than seven years, the increased duration increases the lending rate. Thus, the yield curve can be humped with the maturity. ${ }^{5}$ Ninety per cent of the 168 bank loans from 1990-1995 had maturities of less than one year. This explains the negative coefficient of maturity in the regression.

Collateral is an important factor in loan pricing. The coefficient on fitted collateral is significant at 0.906 and 0.115 in columns three and six, respectively, of table three. The result supports the moral hazard model that riskier borrowers are more likely to be required to provide collateral and be charged a higher interest rate because banks can use collateral to reduce the borrowers' incentives for asset-substitution.

The relationship lending story is found in column three. Borrowers with a longer relationship were charged lower interest rates than are borrowers with a shorter relationship by 125.6 basis points. This shows that a longer bank-borrower relationship leads to better lending rates for borrowers. However, we did not find evidence of this in the second sample period (in column six), probably due to the strong interest rate censoring that started in 1997, which left the bank limited room to favor long-term customers in terms of the lending rate.

Evidence for the predictions on the relationship of maturity and credit rating is also supported. However, the evidence occurs in the period from 1997-2004, which suggests that the loan pricing mechanism has become more rational after the Act. There is a non-monotonic relation between maturity and credit rating in column four, that is, borrowers with good credit ratings have short-term debt because they can get better terms for refinancing. Those with intermediate ratings have long-term debt and those with poor ratings can have only short-term

\footnotetext{
${ }^{5}$ The results are not reported here and are available from the author upon request.
} 
debt because they are rationed out of the long-term debt market, which is consistent with the result of Diamond (1991).

We also find a negative relationship between the length of a bank-borrower relationship and the secured status in column five, which is consistent with the findings of Boot and Thakor (1994). A long-term banking relationship helps to reduce the information asymmetry and the bank requires less collateral to price the loan.

Firm size has a significant impact on loan pricing. Large firms pay 36.9 basis points less than small firms and medium firms pay 18.9 basis points less than small firms. These findings are consistent with the literature, that is, large firms pay lower interest rates than do medium or small firms. This size effect is not found in column three for the first sample period, which suggests the increasing awareness of risks among bank officials and their recognition of firm size as a risk factor.

In general, the results from table three suggest that the bank tightened control of the credit risk of borrowers after the passage of the Commercial Banks Act 1995.

\subsection{Subsample analysis of credit rating}

We now examine whether the credit rating that a bank assigns correctly reflects the financial status of a firm. Panel A of table five provides the summary statistics of the credit ratings for each year since 1997. It shows a clear trend that, over time, the average rating decreases (implying that the average quality of borrower improved) from 4.8 in 1997 to 2.2 in 2004 .

To explore whether the credit rating reflects the financial health of borrowers, we use Altman's Z score as a proxy for the financial status of the borrower (Altman, 2002). It is a balance-sheet method of determining a company's financial health. We used a sub-sample of listed companies where we were able to obtain financial statements for the listed firms. There 
are 17 borrowers with 132 observations from 1997-2004. The Z score is calculated following Altman (2002):

$$
\mathrm{Z}=1.2 \mathrm{WC} \_\mathrm{TA}+1.4 \mathrm{RE} \_\mathrm{TA}+3.3 \mathrm{EBIT} \_\mathrm{TA}+0.6 \mathrm{MV} \_\mathrm{BV}+0.99 \mathrm{~S} \_\mathrm{TA}
$$

where WC_TA: working capital/total assets, RE_TA: retained earnings/total assets, EBIT_TA: earnings before interest and taxes/total assets, MV_BV: market value of the equity/book value of total liabilities, S_TA: sales/total assets, and Z: overall index.

The higher Altman's Z score indicates greater financial health of the borrower. The descriptive statistics and Spearman correlation coefficients for the key variables are reported in panels $\mathrm{B}$ and $\mathrm{C}$ of table five. In panel $\mathrm{B}$, the credit rating has a mean of 1.65 within a range of one to two. Due to the low variation of Credit rating, we use the Spearman rank correlation coefficient to examine the relationship between credit rating and the Altman's Z score, and with each element of the Altman's Z score. The correlation results are presented in panel C. We find that the higher the level of working capital, retained earnings, and EBIT are, the better the credit rating of the borrower. Leverage and sales did not have a significant effect on credit rating, which could result from the short-term characteristics of loans. On average, each loan was granted for 10 months. It is not surprising that the bank is more concerned with liquidity and profitability measures than with leverage and sales, which are more useful in long-term loan risk evaluation.

To supplement our analysis, we use censored-normal regression that fits a model of the interest rate spread on Altman's Z score and other independent variables. The censored-normal regression considers a case in which the dependent variable interest rate spreads are censored differently each year. The results ${ }^{6}$ show that Altman's Z score has a significant negative impact on the interest rate. For a one unit increase in the Altman's Z score, the bank decreases the rate

\footnotetext{
${ }^{6}$ The results are available from the author upon request.
} 
by 11.4 basis points for that borrower. Credit_rating still shows a significant impact on the interest rate, which suggests that credit rating captures factors other than financial information.

Taken together, the findings show that financial ratios, particularly liquidity and profitability measures, are related to credit rating, and that the overall financial status of borrowers is correctly priced by the bank.

\subsection{Non-performing loan performance after the Act on commercial banks}

In the above analysis, we found that the bank tightened its risk control of borrowers after the enactment of the Act on Commercial Banks 1995. If the bank has correctly measured the risks, then we can expect a decrease in the number of non-performing loans, which is a key measure of the quality of a bank's assets. Table six reports the ratio of annual nonperforming loans (NPL ratio) to total credit from 1994-2005. The NPL ratio of the bank reduced from 65 per cent in 1995 to 3.8 per cent in 2005 , which means that 65 per cent of the loans turned out to be bad loans in 1995 whereas only 3.8 per cent of the loans turned out to be bad loans in 2005 . The trend of a reduced NPL ratio was found in many commercial banks. By the end of 2006, the NPL ratio in the four big state commercial banks was 9.22 per cent and the NPL ratio in the

remaining 12 commercial banks was 2.81 per cent. ${ }^{7}$ Our finding that the bank strengthened its credit risk control supports the decrease in the NPL ratios that were found in many commercial banks.

\subsection{Comparison with other banks and other economies.}

\footnotetext{
${ }^{7}$ The four big state commercial banks are the Industrial and Commercial Bank of China, the Bank of China, China Construction Bank, and the Agricultural Bank of China. The remaining 12 commercial banks are the Bank of Communications Co., Ltd., Shenzhen Development Bank Co., Ltd., Guangdong Development Bank, China Everbright Bank Co., Ltd., Hua Xia Bank Co., Ltd., China Minsheng Banking Corporation Ltd., China Merchants Bank Co., Ltd., Shanghai Pudong Development Bank Co., Ltd., China International Trust and Investment Industrial Bank (CITIC), Industrial Bank Co., Ltd., Evergrowing Bank Co., Ltd., and China Zheshang Bank.
} 
After bank loans are classified as non-performing loans, banks usually would sell NPLs to one of the four asset management corporations (AMC) that focus on the recovery of NPLs. Based on various publications from the China Banking Regulatory Commission, we report the recovery rates from the earliest available date in Table seven. On average, the recovery rate was stable at 24 per cent for asset recovery and 20 per cent for cash recovery from 2004 to 2006. The bank has lowest NPL ratio among all the state-owned commercial banks. This should highly correlate with its tight controls on credit risk.

In terms of the overall efficiency of the state bank, Allen et al (2005) compared China with other economies on finance efficiency. China's measure was below all in the sub-sample of LLSV countries (La Porta et al., 1997; 1998). This suggests that China's financial system is under-developed relative to most other countries.

\subsection{Robustness of the results}

A criticism that we anticipate concerns the representativeness of the bank's data. An empirical study based on one bank's data may not speak for the changing lending behavior of banks in China. To address this issue, we employed a database from another government-owned joint commercial bank (Bank B) with more than 30 per cent state ownership. Bank B is located in the same area as Bank A. It has nine sub-branches under its jurisdiction. The database we used covers 1999 to 2004. We conducted a similar regression analysis for Bank B. In general, the results showed that Bank B carefully screens each borrower. We found that firm size, relation length, and past loan status were important factors in pricing. ${ }^{8}$

\footnotetext{
${ }^{8}$ Results are available from the author upon request.
} 


\section{Conclusion}

This paper empirically analyses the lending behavior of a Chinese government bank before and after the enactment of the Act on Commercial Banks 1995. We have three important findings. First, we find that the bank tightened credit terms in granting loans after the passage of the Act in 1995 . To be more specific, the credit rating of the firm, the size of the borrowing firm, the collateral status of a loan, and the ownership of borrowers are all important determining factors in the interest rate. Second, we find that the bank charges SOEs an interest rate higher than that charged to private firms by 6.8 basis points. Third, we find negative interrelationships between loan maturity and the collateral status of a loan which suggests that shortening maturity and asking for collateral are complementary in reducing the information asymmetry between borrowers and lenders.

The findings of this paper are based on the results obtained from an analysis of data from a provincial branch of a government-controlled commercial bank. Although the data are limited to one commercial bank, our findings should apply to other government controlled commercial banks in China, and therefore, can be generalized. If the Act on Commercial Banks 1995 is effective, we can expect that the ratio of nonperforming loans (NPLs) to total credit will decrease for all commercial banks. The evidence shows that the NPL ratio of this bank was reduced, from 65 per cent in 1995 to 3.8 per cent in 2005 . This reduction is consistent with that of other nationwide banks, that is, the NPL ratio in four big state commercial banks was reduced to 9.22 per cent, and the NPL ratio in the remaining 12 commercial banks was reduced to 2.81 per cent. $^{9}$

One weakness of this paper is the unavailability of credit ratings and financial data before 1995. Due to the slow development of risk management in the banking industry in China,

\footnotetext{
${ }^{9}$ The data source is from Wall Street Journal, January 19, 2007.
} 
banks did not perform systematic credit assessment of borrowers in the early 1990s. The unavailability of these data, from another perspective, supports our hypothesis that the state banks started to control credit risk only after the enactment of the Act in 1995.

This is the first empirical research that reports comprehensive evidence of the recent progress in bank lending behavior by evaluating the impact of the Act on Commercial Banks. This investigation is timely, because there is ongoing banking reform in China. It is important because it also provides some insights into a government banking system in transition. The findings of this paper also contribute toward the understanding of the importance of institutional development (i.e., an improved economic and legal environment) in financial markets. Finally, the recent credit risk management failures in the US sub-prime market suggest strongly that a focus on bank lending is not solely in the purview of developing nations, but remains a vital issue worldwide. 


\section{Appendix A: Variable Definitions}

\begin{tabular}{|c|c|}
\hline Variable & Description \\
\hline R_diff & $\begin{array}{l}\text { interest rate spread (in percentage form) between the interest rate that is } \\
\text { charged on the loan and the prime rates of comparable maturity }\end{array}$ \\
\hline Loan size & natural logarithm of the amount of each loan \\
\hline Amount of loan & the amount of each loan in RMB \\
\hline Maturity_year & length of repayment of the loan in years \\
\hline Relation_length & $\begin{array}{l}\text { natural logarithm of (one plus) length of relationship with the current } \\
\text { borrower }\end{array}$ \\
\hline Collateral_loan & 1 if the loan is secured via collateral or guaranteed, 0 otherwise \\
\hline Small firm & 1 if the borrower is a small firm, 0 otherwise \\
\hline Medium firm & 1 if the borrower is a medium firm, 0 otherwise \\
\hline Large firm & 1 if the borrower is a large firm, 0 otherwise \\
\hline State & 1 if the borrower is a SOE, 0 otherwise \\
\hline Private & 1 if the borrower is not a SOE, 0 otherwise \\
\hline Credit_rating & $\begin{array}{l}\text { risk profile score for each firm that is made by a bank officer. It ranges from } \\
1 \text { (best) to } 6 \text { (worst) }\end{array}$ \\
\hline Industry dummies & $\begin{array}{l}\text { six industry affiliations-manufacturing, commerce, construction, } \\
\text { foreign_trade, real_estate, and nonclassifiable establishments }\end{array}$ \\
\hline Acceptance bill & $\begin{array}{l}\text { if the borrower purchased the banker's acceptance bill10 from the bank, } 0 \\
\text { otherwise }\end{array}$ \\
\hline WC_TA & working capital/total assets \\
\hline RE_TA & retained earnings/total assets \\
\hline EBIT_TA & earnings before interest and taxes/total assets \\
\hline MV_BV & market value of the equity/book value of total liabilities \\
\hline S_TA & sales/total assets \\
\hline $\mathrm{Z}$ & Altman Z score \\
\hline BVE_TL & book value of equity/total liability \\
\hline
\end{tabular}

\footnotetext{
${ }^{10}$ When a bank issues a banker's acceptance bill to the purchaser of the bill, the bank has an obligation to make payment to the bearer of the bill at the maturity day. After the payment by the bank to the borrower, the purchaser repays the funds to the bank within 6 months. Hence, the issuance of a banker's acceptance bill is equivalent to the granting of a short-term loan to the purchaser. The procedure for checking and evaluating the risks for issuing a banker's acceptance bill to a purchaser is the same as for granting a loan.
} 


\section{References}

Allen, F, J Qian and M Qian (2005). Law, finance, and economic growth in China. Journal of Financial Economics, 77, 57-116.

Altman, EI (2002). Predicting financial distress of companies: Revisiting the Z-score and ZETA models. Bankruptcy, Credit Risk and High Yield Junk Bonds. Oxford: Blackwell Publishing.

Barth, JR, L Caprio and R Levine (2004). Bank supervision and regulation: What works best? Journal of Financial Intermediation, 13, 205-48.

Basel Committee on Banking Supervision (1999). Consultative Paper on the Principles for the Management of Credit Risk. Basel, Switzerland: Bank for International Settlements. Available from http://www.bis.org/publ/bcbs54.pdf (accessed on 20 August 2007).

Berger, AN and GF Udell (1990). Collateral, loan quality, and bank risk. Journal of Monetary Economics, 25, 21-42.

Berger, AN, GRG Clarke, R Cull, L Klapper and GF Udell (2005). Corporate governance and bank performance: A joint analysis of the static, selection, and dynamic effects of domestic, foreign, and state ownership. Journal of Banking \& Finance, 29, 2179-2221

Besanko, D and AV Thakor (1987). Collateral and rationing: sorting equilibria in monopolistic and competitive credit markets. International Economic Review, 28, 671-689.

Bester, H (1985). Screening vs. rationing in credit market under asymmetric information. American Economic Review, 75, 850-855.

Berger, A, I Hasanc and M Zhou (2009). Bank ownership and efficiency in China: What will happen in the world's largest nation? Journal of Banking \& Finance, 33, 113-130. 
Boot, A and A Thakor (1994). Moral hazard and secured lending in an infinitely repeated credit market game. International Economic Review, 35, 889-920.

Boot, A, A Thakor and G Udell (1991). Secured lending and default risk: equilibrium analysis, policy implications and empirical results, The Economics Journal, 101, 458-472

Chan, Y and G Kanatas (1985). Asymmetric valuations and the role of collateral in loan agreements. Journal of Money, Credit, and Banking, 17, 84-95.

Chang, C, G Liao, X Yu and Z Ni (2009). Information from Relationship Lending: Evidence from Loan Defaults in China. European Banking Center Discussion Paper No. 2009-10S.

Cull, R and L Xu (2000). Bureaucrats, state banks, and the efficiency of credit allocation: The experience of Chinese stated-owned enterprises. Journal of Comparative Economics, 28, 1-31.

Cull, R and L Xu (2003). Who gets credit? The behavior of bureaucrats and state banks in allocating credit to Chinese stated-owned enterprises. Journal of Development Economics, 71, 533-559.

Dennis, S, D Nandy and 1 Sharpe (2000). The determinants of contract terms in bank revolving credit agreements. Journal of Financial and Quantitative Analysis, 35, 87-110.

Diamond, D (1991). Debt maturity structure and liquidity risk. Quarterly Journal of Economics, 106, 709-737.

Elsas, R (2005). Empirical determinants of relationship lending. Journal of Financial Intermediation, 14, 32-57

Gorton, G and A Winton (2003). Financial intermediation. In Handbook of the Economics of Finance, G. M. Constantinides, M. Harris, and R. Stulz (eds.), Amsterdam: North-Holland

Guidelines on making loss provision for bank loans (2002). The People's Bank of China. 
Holmstrom, B and J Tirole (1997). Financial intermediation, loanable funds and the real sector. Quarterly Journal of Economics, 112, 663-691.

Hwa, EC and Y Lei (2010). China's Banking Reform and Profitability. Review of Pacific Basin Financial Markets and Policies, 13, 215-236.

La Porta, R, F Lopez-de-Silanes and G Zamarripa (2003). Related lending. Quarterly Journal of Economics, 118, 231-268.

La Porta, R, F Lopez-de-Silanes and A Shleifer (2002). Government ownership of banks. The Journal of Finance, 57, 265-301.

La Porta, R, F Lopez-de-Silanes, A. Shleifer and R. Vishny (1997). Legal determinants of external finance, Journal of Finance, 52,1131-1150

La Porta, R, F Lopez-de-Silanes, A. Shleifer and R. Vishny (1998). Law and finance. Journal of Political Economy, 106, 1113-1155.

Lardy, N (1998). China's Unfinished Economic Revolution. Washington, D.C.: Brookings Institutions Press.

Li, S, F Liu, S Liu and G. A. Whitmore (2001). Comparative Performance of Chinese Commercial Banks: Analysis, Findings and Policy Implications, Review of Quantitative Finance and Accounting, 16, 149-170.

Liu, M (2005). Construction of the Legal Framework for Banking Regulation and Supervision in Modern China, Paper presented at the 22nd Congress on the Law of the World, 2005.

Long, HW (1974). An analysis of the determinants and predictability of agency ratings of domestic utility bond quality. The Journal of Finance, 29,1591-1592. 
Lou, J (1993). Financia Systems and Policy. Harvard Institute of International Development Conference, Cambridge, MA.

Morsman, E (1986). Commercial loan structuring. Journal of Commercial Bank Lending, 68, 220.

Myers, SC (1977). Determinants of corporate borrowing. Journal of Financial Economics, 5, 147-175.

Petersen, MA and RG Rajan (1994). The benefits of lending relationships: Evidence from small business data. The Journal of Finance, 49, 3-37.

Rajan, RG (1992). Insiders and outsiders: The choice between informed and arm's-length debt. The Journal of Finance, 47, 1367-1400.

Rowe, W, W Shi and C Wang (2011). Board governance and profitability of Chinese banks. Bank and Bank Systems. Forthcoming.

Sharpe, SA (1990). Asymmetric information, bank lending, and implicit contracts: A stylized model of customer relationships. The Journal of Finance, 45, 1069-1087.

Statistical Yearbook of China (1997-2002). China Statistics Press, Beijing.

Stiglitz, J and A Weiss (1981). Credit rationing in markets with imperfect information. American Economic Review, 71, 393-410.

Stulz, R (1990). Managerial discretion and optimal financing policies. Journal of Financial Economics, 26, 3-27.

World Bank (2002). Bank Loan Classification and Provisioning Practices in Selected Developed and Emerging Countries (a Survey of Current Practices in Countries Represented on the Basel Core Principles Liaison Group). Washington, DC: International Bank for Reconstruction and Development, Finance Forum. 


\section{Table 1: Descriptive data}

This data set comprises 2459 bank loans from 1990 to 2004. Panel A presents the basic data on lending terms in the whole sample. Panel B present the subsample data classified according to ownership. Panel C present the subsample data classified according to collateral status. Panel D presents the subsample data classified according to firm size.

\begin{tabular}{|c|c|c|c|c|c|}
\hline \multirow{2}{*}{$\begin{array}{l}\text { Panel A } \\
\text { Variables }\end{array}$} & \multicolumn{5}{|c|}{ Whole Sample } \\
\hline & $\mathrm{N}$ & Mean & Std. Dev. & Min. & Max. \\
\hline Amount & & & & & \\
\hline loan(RMB) & 2459 & $6,970,078$ & $13,500,000$ & 22,400 & $300,000,000$ \\
\hline Loan size & 2459 & 14.720 & 1.500 & 10.017 & 19.519 \\
\hline R_diff(\%) & 2459 & 0.688 & 1.118 & -4.980 & 5.760 \\
\hline Maturity & 2459 & 0.795 & 0.506 & 0.077 & 7.003 \\
\hline Credit_rating & 2262 & 3.295 & 1.518 & 1.000 & 6.000 \\
\hline Relation_length & 2459 & 0.653 & 0.602 & 0.000 & 2.140 \\
\hline Panel B & \multicolumn{2}{|c|}{ SOEs } & \multicolumn{2}{|c|}{ Private firms } & \\
\hline Variables & $\mathrm{N}$ & Mean & $\mathrm{N}$ & Mean & Difference \\
\hline Amount of loan & 1660 & $7,093,843$ & 799 & $6,712,945$ & 388,898 \\
\hline Loan size & 1660 & 14.799 & 799 & 14.557 & $0.242 * *$ \\
\hline R_diff & 1660 & 0.615 & 799 & 0.840 & $-0.225 * *$ \\
\hline Maturity & 1660 & 0.812 & 799 & 0.761 & $0.051 * *$ \\
\hline Credit_rating & 1536 & 3.136 & 726 & 3.632 & $-0.496^{* *}$ \\
\hline Relation_length & 1660 & 0.715 & 799 & 0.526 & $0.188 * *$ \\
\hline Panel C & \multicolumn{2}{|c|}{ Collateral_loan } & \multicolumn{2}{|c|}{ Noncollateral_loan } & \\
\hline Variables & $\mathrm{N}$ & Mean & $\mathrm{N}$ & Mean & Difference \\
\hline Amount of loan & 1461 & $8,214,867$ & 998 & $5,147,797$ & $3,067,071 * *$ \\
\hline Loan size & 1461 & 14.877 & 998 & 14.491 & $0.386 * *$ \\
\hline R_diff & 1461 & 0.786 & 998 & 0.545 & $0.241 * *$ \\
\hline Maturity & 1461 & 0.805 & 998 & 0.781 & 0.024 \\
\hline Credit_rating & 1338 & 3.373 & 924 & 3.183 & $0.190 *$ \\
\hline Relation_length & 1461 & 0.655 & 998 & 0.652 & 0.003 \\
\hline Panel D & \multicolumn{2}{|c|}{ Small firm } & \multicolumn{2}{|c|}{ Medium firm } & Large firm \\
\hline Variables & $\mathrm{N}$ & Mean & $\mathrm{N}$ & Mean & Mean \\
\hline Amount of loan & 754 & $3,305,662$ & 1150 & $5,407,841$ & $15,200,000$ \\
\hline Loan size & 754 & 14.088 & 1150 & 14.621 & 15.783 \\
\hline R_diff & 754 & 1.139 & 1150 & 0.581 & 0.298 \\
\hline Maturity & 754 & 0.763 & 1150 & 0.797 & 0.838 \\
\hline Credit_rating & 703 & 3.954 & 1071 & 3.120 & 2.730 \\
\hline Relation_length & 754 & 0.504 & 1150 & 0.649 & 0.865 \\
\hline
\end{tabular}

Note: * Significant at the $5 \%$ level; ** significant at the $1 \%$ level. 
Table 2: Individual loan terms and industry distribution across the two sample periods

\begin{tabular}{|c|c|c|c|c|c|c|c|c|c|c|}
\hline \multirow{3}{*}{$\begin{array}{l}\text { Variables } \\
\text { Panel A }\end{array}$} & \multicolumn{4}{|c|}{$1990-1995$} & \multicolumn{5}{|c|}{$1997-2004$} & \multirow[b]{3}{*}{ Difference } \\
\hline & \multicolumn{2}{|r|}{ SOEs } & \multicolumn{2}{|c|}{ Private firms } & \multirow{2}{*}{ Difference } & \multicolumn{2}{|r|}{ SOEs } & \multicolumn{2}{|c|}{ Private firms } & \\
\hline & $\mathrm{N}$ & Mean & $\mathrm{N}$ & Mean & & $\mathrm{N}$ & Mean & $\mathrm{N}$ & Mean & \\
\hline$\overline{\text { Amount of loan }}$ & 99 & $1,650,960$ & 69 & $1,117,246$ & 533,713 & 1489 & $7,638,317$ & 661 & $7,860,144$ & 221,826 \\
\hline Loan size & 99 & 13.505 & 69 & 13.063 & $0.442 *$ & 1489 & 14.916 & 661 & 14.814 & 0.102 \\
\hline R_diff & 99 & 2.577 & 69 & 2.640 & -0.063 & 1489 & 0.410 & 661 & 0.525 & $-0.115^{* *}$ \\
\hline Maturity & 99 & 0.760 & 69 & 0.499 & $0.261 * *$ & 1489 & 0.817 & 661 & 0.791 & 0.026 \\
\hline Credit_rating & 86 & - & 69 & - & - & 1489 & 2.931 & 661 & 3.311 & $-0.38 * *$ \\
\hline Relation_length & 99 & 0.114 & 69 & 0.173 & -0.059 & 1489 & 0.779 & 661 & 0.600 & $0.179 * *$ \\
\hline Panel B & $\mathrm{N}$ & Percentage & $\mathrm{N} \mathrm{I}$ & Percentage & & $\mathrm{N}$ & Percentage & $\mathrm{N}$ & Percentage & \\
\hline$\overline{\text { Collateral_loan }}$ & 99 & 63.6 & 69 & 52.2 & 11.4 & 1489 & 53.2 & 661 & 72.3 & $-19.1 * *$ \\
\hline Small firm & 99 & 46.5 & 69 & 76.8 & $-30.3 * *$ & 1489 & 23.34 & 661 & 39.79 & $-16.45^{* *}$ \\
\hline Medium firm & 99 & 49.5 & 69 & 23.2 & $26.3 * *$ & 1489 & 49.2 & 661 & 46.0 & 3.2 \\
\hline Large firm & 99 & 4 & 69 & 0 & $-4 *$ & 1489 & 30.4 & 661 & 14.2 & $16.2 * *$ \\
\hline Panel C & $\mathrm{N}$ & Percentage & $\mathrm{N} \mathrm{I}$ & Percentage & & $\mathrm{N}$ & Percentage & $\mathrm{N}$ & Percentage & \\
\hline Commerce & 99 & 31.3 & 69 & 37.7 & 6.4 & 1489 & 28.6 & 661 & 41.3 & $-12.7 * *$ \\
\hline Construction & 99 & 1 & 69 & 2 & -1 & 1489 & 6.8 & 661 & 4.4 & $2.4 * *$ \\
\hline Foreign trade & 99 & 15.1 & 69 & 0 & $15.1 * *$ & 1489 & 26.5 & 661 & 2.4 & $24.1 * *$ \\
\hline Manufacturing & 99 & 50.5 & 69 & 53.6 & -3.1 & 1489 & 24.5 & 661 & 29.0 & $-4.5 *$ \\
\hline $\begin{array}{l}\text { Nonclassifiable } \\
\text { Establishment }\end{array}$ & 99 & 2 & 69 & 1.44 & 0.56 & 1489 & 12.0 & 661 & 9.2 & $2.8^{*}$ \\
\hline Real Estate & 99 & 0 & 69 & 4 & -4 & 1489 & 1.4 & 661 & 13.6 & $-12.2 * *$ \\
\hline
\end{tabular}

Note: $*$ Significant at the $5 \%$ level; $* *$ significant at the $1 \%$ level. 


\section{Table 3: Interest rate regressions}

This table estimates the factors that affect the maturity, collateral status, and interest rate simultaneously. Relation_length, Maturity, and Credit_rating ${ }^{11}$ are centered by subtraction from the mean to avoid the multicollinearity problem. This rescaling has no effect on the correlation properties of the rescaled variable. The absolute value of the t-statistic is in parentheses.

\begin{tabular}{|c|c|c|c|c|c|c|}
\hline & \multicolumn{3}{|c|}{ Panel A } & \multicolumn{3}{|c|}{ Panel B } \\
\hline & \multicolumn{3}{|c|}{ 1990-1995 } & \multicolumn{3}{|c|}{$1997-2004$} \\
\hline & $\begin{array}{c}\text { Maturity } \\
\text { (1) }\end{array}$ & $\begin{array}{l}\text { Collateral } \\
\text { Loan } \\
\text { (2) }\end{array}$ & $\begin{array}{c}\text { R_diff } \\
\text { (3) }\end{array}$ & $\begin{array}{c}\text { Maturity } \\
\text { (4) }\end{array}$ & $\begin{array}{l}\text { Collateral } \\
\text { Loan }\end{array}$ & R_diff \\
\hline State & $\begin{array}{c}0.754 * * \\
(4.89)\end{array}$ & $\begin{array}{l}1.517 \\
(0.03)\end{array}$ & $\begin{array}{l}0.117 \\
(0.37)\end{array}$ & $\begin{array}{l}0.039 \\
(0.52)\end{array}$ & $\begin{array}{l}0.043 \\
(0.29)\end{array}$ & $\begin{array}{c}0.068 * * \\
(2.57)\end{array}$ \\
\hline State*credit rating & & & & & & $\begin{array}{c}0.046^{* * *} \\
(2.84)\end{array}$ \\
\hline Fitted maturity & & $\begin{array}{l}-1.324 \\
(-0.04)\end{array}$ & $\begin{array}{c}-1.424 * * \\
(-5.47)\end{array}$ & & $\begin{array}{c}-1.823 * * \\
(-20.68)\end{array}$ & $\begin{array}{l}-0.156 \\
(-1.22)\end{array}$ \\
\hline Fitted collateral & $\begin{array}{c}-0.858 * * \\
(-4.71)\end{array}$ & & $\begin{array}{c}0.906 * * \\
(2.98)\end{array}$ & $\begin{array}{c}-0.110 * * \\
(-2.46))\end{array}$ & & $\begin{array}{c}0.115^{* *} \\
(4.16)\end{array}$ \\
\hline Medium firm & $\begin{array}{c}-0.552 * * \\
(-3.06)\end{array}$ & $\begin{array}{l}-1.07 \\
(-0.01)\end{array}$ & $\begin{array}{l}-0.395 \\
(-1.26)\end{array}$ & $\begin{array}{l}0.138 \\
(1.15)\end{array}$ & $\begin{array}{l}0.322 \\
(1.14)\end{array}$ & $\begin{array}{c}-0.189 * * \\
(-4.69)\end{array}$ \\
\hline Large firm & $\begin{array}{l}0.127 \\
(0.33)\end{array}$ & $\begin{array}{c}0.608 * * \\
(21.61)\end{array}$ & $\begin{array}{l}0.159 \\
(0.17)\end{array}$ & $\begin{array}{l}0.243 * \\
(2.22)\end{array}$ & $\begin{array}{c}0.501 * \\
(1.99)\end{array}$ & $\begin{array}{c}-0.369 * * \\
(-6.79)\end{array}$ \\
\hline Relation_length & & $\begin{array}{l}0.216 \\
(0.01)\end{array}$ & $\begin{array}{c}-1.256^{* *} \\
(-2.33)\end{array}$ & & $\begin{array}{c}-0.03^{*} \\
(-2.3)\end{array}$ & $\begin{array}{l}0.033 \\
(1.35)\end{array}$ \\
\hline Credit_rating & & & & $\begin{array}{l}0.016 \\
(1.58)\end{array}$ & $\begin{array}{l}0.027 \\
(1.51)\end{array}$ & $\begin{array}{l}-0.009 \\
(-0.63)\end{array}$ \\
\hline Credit_rating ${ }^{2}$ & & & & $\begin{array}{c}-0.004 * * \\
(-2.9)\end{array}$ & $\begin{array}{c}-0.03^{*} \\
(-2.3)\end{array}$ & \\
\hline Acceptance bill & & & & & & $\begin{array}{l}-0.091 \\
(-1.42)\end{array}$ \\
\hline Commerce & & & $\begin{array}{l}0.402 \\
(1.21)\end{array}$ & & & $\begin{array}{c}0.066^{* * *} \\
(2.23)\end{array}$ \\
\hline Construction & & & $\begin{array}{l}1.112 \\
(1.09)\end{array}$ & & & $\begin{array}{l}0.059 \\
(1.06)\end{array}$ \\
\hline Foreign trade & & & $\begin{array}{l}0.502 \\
(0.89)\end{array}$ & & & $\begin{array}{l}-0.031 \\
(-0.77)\end{array}$ \\
\hline $\begin{array}{l}\text { Nonclassifiable } \\
\text { estab. }\end{array}$ & & & $-2.632 * *$ & & & -0.002 \\
\hline Real_estate & & & $\begin{array}{l}(-2.61) \\
-1.986 \\
(-1.89)\end{array}$ & & & $\begin{array}{c}(-0.04) \\
0.038 \\
(0.7)\end{array}$ \\
\hline Constant & $\begin{array}{c}0.930 * * \\
(6.67)\end{array}$ & $\begin{array}{l}0.661 \\
(0.02)\end{array}$ & $\begin{array}{c}3.018 * * \\
(6.23)\end{array}$ & $\begin{array}{c}0.670^{* *} \\
(18.69)\end{array}$ & $\begin{array}{l}1.121^{* *} \\
(16.57)\end{array}$ & $\begin{array}{c}0.481 * * \\
(7.05)\end{array}$ \\
\hline Year Dummies & & & Yes & & & Yes \\
\hline Observations & 168 & 168 & 168 & 1972 & 1972 & 1972 \\
\hline AIC & & 1099 & & & 5615 & \\
\hline Log likelihood & & -516.54 & & & -2767 & \\
\hline Schwarz Criterion & & 1202 & & & 5845 & \\
\hline
\end{tabular}

Note: $*$ Significant at the $5 \%$ level; ** significant at the $1 \%$ level.

\footnotetext{
${ }^{11}$ The bank did not have credit rating system before 1997, thus Credit rating is available only from 1997.
} 


\section{Table 4: Yearly statistics for individual loan}

Panel A Yearly statistics for individual loans for the entire sample

\begin{tabular}{|c|c|c|c|c|c|c|c|c|c|}
\hline & \multicolumn{3}{|c|}{ Amount of loan } & \multicolumn{3}{|c|}{ R_diff } & \multicolumn{3}{|c|}{ Credit_rating } \\
\hline & SOEs & $\begin{array}{c}\text { Private } \\
\text { firms }\end{array}$ & diff & SOEs & $\begin{array}{c}\text { Private } \\
\text { firms }\end{array}$ & diff & SOEs & $\begin{array}{c}\text { Private } \\
\text { firms }\end{array}$ & diff \\
\hline 1990 & $5,110,000$ & 480,000 & $4,630,000$ & 0.216 & 2.390 & -2.174 & - & - & - \\
\hline 1991 & $1,296,364$ & 90,000 & $1,206,364$ & 1.430 & 2.016 & -0.586 & - & - & - \\
\hline 1992 & $1,264,000$ & 690,000 & 574,000 & 2.998 & 0.738 & 2.260 & - & - & - \\
\hline 1993 & $1,973,529$ & $1,015,455$ & 958,074 & 2.986 & 1.631 & 1.355 & - & - & - \\
\hline 1994 & $1,343,857$ & $1,265,185$ & 78,672 & 2.597 & 3.239 & -0.641 & - & - & - \\
\hline 1995 & $2,330,571$ & $1,306,053$ & $1,024,518$ & 3.617 & 3.385 & 0.232 & - & - & - \\
\hline 1996 & $3,391,250$ & $1,355,255$ & $2,035,995^{*}$ & 1.547 & 1.427 & 0.120 & - & - & - \\
\hline 1997 & $1,894,794$ & $2,649,346$ & $-754,552$ & 0.709 & 0.795 & -0.085 & 4.826 & 4.870 & -0.043 \\
\hline 1998 & $3,287,500$ & $1,995,682$ & $1,291,818$ & 0.469 & 0.309 & 0.159 & 4.121 & 4.364 & -0.242 \\
\hline 1999 & $4,620,315$ & $2,512,609$ & $2,107,706 * *$ & 0.742 & 0.961 & $-0.219 *$ & 3.132 & 3.710 & $-0.578 * *$ \\
\hline 2000 & $8,760,138$ & $5,318,038$ & $3,442,100$ & 0.631 & 0.844 & $-0.213^{* *}$ & 3.144 & 3.184 & -0.040 \\
\hline 2001 & $8,640,087$ & $8,406,182$ & 233,905 & 0.481 & 0.479 & 0.002 & 2.737 & 2.903 & -0.166 \\
\hline 2002 & $6,750,325$ & $8,923,946$ & $-2,173,621$ & 0.373 & 0.374 & -0.001 & 2.784 & 2.701 & 0.082 \\
\hline 2003 & $7,971,622$ & $11,200,000$ & $-3,228,378$ & 0.183 & 0.176 & 0.007 & 2.603 & 2.475 & 0.128 \\
\hline 2004 & $12,700,000$ & $17,100,000$ & $-4,400,000$ & 0.221 & 0.324 & $-0.103 *$ & 2.174 & 2.410 & -0.235 \\
\hline
\end{tabular}

Panel B Yearly observations for eliminated customers

\begin{tabular}{lcc}
\hline & \multicolumn{2}{c}{ observations } \\
\cline { 2 - 3 } & SOEs & Private firms \\
\hline 1990 & 2 & 5 \\
1991 & 10 & 2 \\
1993 & 13 & 6 \\
1994 & 14 & 11 \\
1995 & 29 & 25 \\
1996 & 31 & 28 \\
1997 & 32 & 35 \\
1998 & 55 & 56 \\
1999 & 11 & 8 \\
2000 & 4 & 2 \\
2001 & 5 & 2 \\
2002 & 5 & 3 \\
2003 & 1 & 1 \\
2004 & 0 & 0 \\
\end{tabular}


Table 5: Analysis of credit rating and Altman's Z score

Panel A: Summary statistics of Credit_rating. It ranged from 1 (best) to 6 (worst).

\begin{tabular}{cccc}
\hline Year & Obs. & Credit rating & Std. Dev. \\
\hline 1997 & 184 & 4.848 & 0.511 \\
1998 & 110 & 4.218 & 1.207 \\
1999 & 190 & 3.342 & 1.389 \\
2000 & 215 & 3.158 & 1.473 \\
2001 & 312 & 2.792 & 1.374 \\
2002 & 349 & 2.768 & 1.348 \\
2003 & 392 & 2.577 & 1.355 \\
2004 & 233 & 2.236 & 1.021 \\
\hline
\end{tabular}

Panel B: Subsample that comprises 132 bank loans to listed firms from 1997 to 2004. It provides descriptive statistics for credit rating, Altman's Z score, and each element of Altman's Z score.

\begin{tabular}{lccccc}
\hline Variable & $\mathrm{N}$ & Mean & Minimum & Maximum & Std. Dev. \\
\hline Credit_rating & 123 & 1.642 & 1.000 & 2.000 & 0.481 \\
Z Score & 132 & 2.260 & -1.310 & 7.853 & 1.322 \\
WC_TA & 132 & 0.094 & -0.637 & 0.669 & 0.198 \\
RE_TA & 132 & 0.068 & -0.481 & 0.230 & 0.086 \\
EBIT_TA & 132 & 0.045 & -0.108 & 0.151 & 0.046 \\
BVE_TL & 132 & 1.470 & 0.185 & 6.072 & 1.046 \\
MV OF EQUITY_TL & 132 & 2.361 & 0.515 & 11.196 & 1.858 \\
SALES_ASSET & 132 & 0.488 & 0.000 & 1.286 & 0.258 \\
\hline
\end{tabular}


Panel C: Spearman correlation coefficients.

\begin{tabular}{|c|c|c|c|c|c|c|c|c|c|}
\hline & $\begin{array}{l}\text { Credit } \\
\text { rating }\end{array}$ & R_DIFF & ZSCORE & WC_TA & RE_TA & EBIT_TA & BVE_TL & MVEQUITY & SALES_ASSET \\
\hline R_DIFF & $.244 * *$ & 1.000 & & & & & & & \\
\hline WC_TA & $-.328 * *$ & $-.325 * *$ & $.441 * *$ & 1.000 & & & & & \\
\hline RE_TA & $-.337 * *$ & -.060 & $.247 * *$ & -.047 & 1.000 & & & & \\
\hline EBIT_TA & $-.375^{* *}$ & .066 & $.407 * *$ & $-.215^{*}$ & $.678 * *$ & 1.000 & & & \\
\hline SALES_ASSET & -.119 & .047 & $.447 * *$ & $-.234 * *$ & $.292 * *$ & $.618 * *$ & -.074 & .066 & 1.000 \\
\hline
\end{tabular}

* Correlation is significant at the 0.05 level (2-tailed). ** Correlation is significant at the 0.01 level (2-tailed). 
Table 6: Nonperforming loan performance before and after the Act

The NPL ratio is calculated as the annual nonperforming loans divided by the annual total amount of credit.

\begin{tabular}{cc} 
Year & NPL ratios (per cent) \\
1994 & 65 \\
1995 & 65 \\
1996 & 63 \\
1997 & 52 \\
1998 & 45 \\
1999 & 41 \\
2000 & 38 \\
2001 & 35 \\
2002 & 43 \\
2003 & 28 \\
2004 & 11 \\
2005 & 3.80 \\
\hline
\end{tabular}




\section{Table 7: Recovery rate of NPLs}

This table presents the recovery rates from the four asset management corporations. Accumulated Disposal refers to the accumulated amount of cash and non-cash assets recovered as well as loss incurred by the end of the reporting period. Disposal Ratio is calculated as accumulated disposal divided by total NPAs purchased. Asset Recovery Ratio is calculated as total assets recovered divided by accumulated disposal. Cash Recovery Ratio is defined as cash recovered divided by accumulated disposal.

\begin{tabular}{|c|c|c|c|}
\hline The Four Asset Management Corporations & $\begin{array}{l}2004 \\
(\mathrm{Q} 4)\end{array}$ & $\begin{array}{l}2005 \\
(\mathrm{Q} 4)\end{array}$ & $\begin{array}{l}2006 \\
(\mathrm{Q} 1)\end{array}$ \\
\hline $\begin{array}{l}\text { Accumulated Disposal in RMB } 100 \text { mil } \\
\text { (Cash Recovered in RMB } 100 \text { mil) } \\
\text { Disposal Ratio } \\
\text { Asset Recovery Ratio } \\
\text { Cash Recovery Ratio }\end{array}$ & $\begin{array}{l}6750.6 \\
1370.0 \\
53.96 \% \\
25.48 \% \\
20.29 \%\end{array}$ & $\begin{array}{l}8397.5 \\
1766.0 \\
66.74 \% \\
24.58 \% \\
21.03 \%\end{array}$ & $\begin{array}{l}8663.4 \\
1805.6 \\
68.61 \% \\
24.20 \% \\
20.84 \%\end{array}$ \\
\hline $\begin{array}{l}\text { China Huarong Asset Management Corporati } \\
\text { Accumulated Disposal in RMB } 100 \text { mil } \\
\text { (Cash Recovered in RMB } 100 \text { mil) } \\
\text { Disposal Ratio } \\
\text { Asset Recovery Ratio } \\
\text { Cash Recovery Ratio }\end{array}$ & $\begin{array}{c}2095.4 \\
413.4 \\
59.77 \% \\
25.29 \% \\
19.73 \%\end{array}$ & $\begin{array}{c}2433.8 \\
543.9 \\
69.17 \% \\
26.92 \% \\
22.35 \%\end{array}$ & $\begin{array}{c}2468.0 \\
546.6 \\
70.11 \% \\
26.50 \% \\
22.15 \%\end{array}$ \\
\hline \multicolumn{4}{|l|}{ China Great Wall Asset Management Corporation } \\
\hline $\begin{array}{l}\text { Accumulated Disposal in RMB } 100 \text { mil } \\
\quad \text { (Cash Recovered in RMB } 100 \text { mil) } \\
\text { Disposal Ratio } \\
\text { Asset Recovery Ratio } \\
\text { Cash Recovery Ratio }\end{array}$ & $\begin{array}{c}2099.1 \\
215.7 \\
61.91 \% \\
14.43 \% \\
10.27 \%\end{array}$ & $\begin{array}{c}2633.9 \\
273.5 \\
77.88 \% \\
12.90 \% \\
10.39 \%\end{array}$ & $\begin{array}{c}2707.8 \\
278.3 \\
80.11 \% \\
12.70 \% \\
10.28 \%\end{array}$ \\
\hline \multicolumn{4}{|l|}{ China Orient Asset Management Corporation } \\
\hline $\begin{array}{l}\text { Accumulated Disposal in RMB } 100 \text { mil } \\
\text { (Cash Recovered in RMB } 100 \text { mil) } \\
\text { Disposal Ratio } \\
\text { Asset Recovery Ratio } \\
\text { Cash Recovery Ratio }\end{array}$ & $\begin{array}{c}1045.5 \\
232.9 \\
41.42 \% \\
29.50 \% \\
22.27 \%\end{array}$ & $\begin{array}{c}1317.6 \\
320.1 \\
52.08 \% \\
28.73 \% \\
24.30 \%\end{array}$ & $\begin{array}{c}1419.9 \\
328.1 \\
56.13 \% \\
27.16 \% \\
23.11 \%\end{array}$ \\
\hline \multicolumn{4}{|l|}{ China Cinda Asset Management Corporation } \\
\hline $\begin{array}{l}\text { Accumulated Disposal in RMB } 100 \text { mil } \\
\text { (Cash Recovered in RMB } 100 \text { mil) } \\
\text { Disposal Ratio } \\
\text { Asset Recovery Ratio } \\
\text { Cash Recovery Ratio }\end{array}$ & $\begin{array}{c}1510.6 \\
508.1 \\
48.90 \% \\
38.29 \% \\
33.64 \%\end{array}$ & $\begin{array}{c}2012.1 \\
628.4 \\
63.82 \% \\
34.30 \% \\
31.23 \%\end{array}$ & $\begin{array}{c}2067.7 \\
652.6 \\
64.69 \% \\
34.46 \% \\
31.56 \%\end{array}$ \\
\hline
\end{tabular}

